\title{
INTEGRATING ISLAMIC DESIGN PRINCIPLES FOR ACHIEVING FAMILY PRIVACY IN RESIDENTIAL ARCHITECTURE
}

| Received September 25th, 2017 | Accepted November 27th, 2017 | Available online June 15th, 2018 |

DOI http://dx. doi. org/10.18860/jia.v5i1.4407 |

\section{Hamza Babangida}

Department of Architecture,

Ahmadu Bello University, Zaria,

Kaduna State, Nigeria

babanhamza@gmail.com

Halima Sani-Katsina

Department of Architecture,

Ahmadu Bello University, Zaria,

Kaduna State, Nigeria

\begin{abstract}
Islamic Design Principles (IDP) are general guides in the context of the Islamic legal system (Sharia) abstracted for application in the management of the existing Muslim built environment and which could be used for the designing new buildings. Accordingly, they were developed from various Sharia sources among which include the Qur'an and the Hadith, as primary sources. The aim of this paper is to identify Islamic Design Principles which apply to architecture and to use same to demonstrate how they could be applied to achieve family privacy in residential design of the Muslim faithful. The research methodology involved literature search on extant works which identified Islamic Principles and their relevance to residential architecture on one hand and documentation of floor plans of existing houses designed for and occupied by Muslims in Nigeria. A four bedroom duplex among the documented houses was used to demonstrate how family privacy could be achieved using the Islamic Design Principles (IDP) at various design stages such as spatial rearrangement, reorientation, and reconfiguration of functional spaces without compromising global design criteria. In the redesigned floor plans, the design elements that were integrated include those which affected bedrooms, living rooms and other spaces for family interactions to reflect family privacy needs. Overall, the outcome of this paper adds to our understanding of the role the Islamic Design Principles (IDP) could play in no distant future on novel design approaches that support the use of new structural forms, shape and design elements which provides to privacy needs of Muslim faithful as well as satisfy universal design requirements. This paper will find practical implication if it is used as theoretical as well practical support to professionals in designing residences which address specific spiritual values of residents
\end{abstract}

KEYWORDS:

Islamic Design Principles, Privacy, Residential Architecture, Design, Sharia

\section{INTRODUCTION}

The Islamic Design Principles (IDP) are general guides which are sourced from the Islamic legal system (Sharia) for use in managing various aspects and complexities of Muslim built environment on issues that may arise between and among neighbors with respect to their buildings, and in developing new ones. From an architectural point of view, these principles were actually referred to assets of principles sourced from the Sharia that guide the architectural design of housing and other buildings [1], [2] \& [3]. The Islamic law or the Islamic legal system (Sharia) explained both how a Muslim should live his life and determine his relationship with the social and physical environments [4], [5], [6], [7], [8] \& [9]. Operationally, the Sharia was defined by Kamali (1989) cited in [7] as 'commands, prohibitions, guidance and principles revealed and addressed to the Muslim society pertaining to their conduct'. Historically, it is believed to come into being from the seventh century, which equates to one thousand four hundred years today [10]. It develops with the passage of time and in response to the dynamics of human needs both as a guide and a full system relevant for the survival of the Muslim faithful [7], [11]. For the Muslim faithful, the concept of the Sharia is rooted in faith and serves as the foundation of a belief and as a basis for accepting ideas without demanding strict evidence, a context which [12] referred to as a general prerequisite of most, if not all religious doctrines.

The works of [5] reported how jurist have extensively applied principles derived from the Shariah sources to resolve a conflict among neighbors and others and thereby contributing to the efficient built environment. Examples of some of these IDP from the Quran and Hadith which were duly interpreted and 
applied as Islamic Design Principles for guiding development include those which address Harm (Qur'an 4;29, 44:10,-11) privacy (Qur'an 18;80, 24;27). And at urban scale these IDP were applied to determine the standard widths of through streets as 3.23-3.5m meters (based upon the Hadiths which prescribe 7 cubits), the minimum height of flying buttress as 3.5 meters high, width of cul-de-sac as 1.8 meters as well as minimum horizontal and vertical dimensions of fully loaded camel to determine thoroughfare between houses. Similarly, in the study area, the work of [6] reviewed the works of Fodiwa trio (Uthman dan Fodio, his brother Abdallah and son Mohammad Bello who unified northern Nigeria and other territories into an Islamic State from 1808 until 1903) [13], [14] on the interpretation and application of IDP on built environment. The trio developed treatises to address growth and change in the 19th century for the Hausa rulers for their use in managing the built environment as the need arises. Their first treatise Qa'ida, al-darar yuzal (harm should be eliminated) was most applied to issues on built environment specifically on an aspect which affects construction and the management of the built environment at the neighborhood level. Their works lead to development of six categories of rules concerning Harim, (zone surrounding city) ihya al-Mawat (revivification of dead land), Haqq al-Irtifaq (rights of abutting properties), alTuruq al-Amma wa Haqquha (right of public streets), al-Marafiq wa Man'al-Darar (prevention of damages to adjacent structures and al-Daman wa al-Masuliyya Indath al-Darar (liability and responsibility for creating damages). The application of the IDP in northern Nigerian Muslim cities addressed fundamental issues of equity and justice. The manifestation of the application of some of these treatises on residential houses to achieve privacy could be discerned in the separation of male and female spaces, provision of entrance hall (zaure) to screen visitors, as well as creation of women area at the furthest area of the house [15]. It also influences the siting of toilet facility in relation to the Qibla directions [16].

The residential house from Islamic perspective has been defined as the place in which an individual protects himself from the climatic elements and in which he finds freedom from restrictions and pressures of society; a place of rest for the body and relaxation for the mind [6], [17], a definition which was based in the context of a verse from the Quran (16: 80 ). The house as an entity has the capacity to serve as an avenue for reflection of this will and consciousness [18] due partly to acceptance of the house as a cultural sphere and the social relevance of the Islamization of space [19]. According to Sixsmith [6], a house consists of three key components; personal, social and physical. The personal home according to the scholar serves as an extension of oneself with central emotional expression, the social home, on the other hand, serves as a place to share, entertain, and build relationships, and lastly, the physical home, presents itself to the occupant as the physical structure, space and architectural style. Similarly, the works of Altman \& Chemers, (1980) cited in [21] highlight the importance of macro-level factors, such as religion in shaping perceptions of home. In line with the objective of this study, many extant studies expose the relevance of belief system to the built environment. Example of such studies includes Islamic considerations on providing family privacy and moderation in the residential house [22] achieving various levels of privacy in-house designs [23], resort design considerations from Islamic values [24] and hospitality design values [25]. This study, therefore, aims to build upon existing knowledge base on IDP to demonstrate to architects and other professionals in the built environment of the possibilities of integrating IDP to achieve family privacy and in line with universal design principles

The principal aim of this paper is to expose various architectural design approaches based upon Islamic design principles that can be used to achieve privacy in the design of the Muslim client's house. Specifically, the paper targets to achieve the following key objectives:

1. Provide contextual understanding and basis of using Islamic design principles as the design guide as sourced from the Sharia which relates to architecture in general, and specifically those that could be applied to achieve privacy in the residential house

2. Explain how the principles could be integrated into the design process to achieve an appropriate design that will ultimately provide the privacy requirements of Muslim family

3. Demonstrate using a design-based approach, a redesign of the existing duplex (as case study) how spaces and other design elements could be integrated to achieve an architectural design which provides the required privacy of residents.

\section{METHODS}

The research methodology adopted in the study was qualitative in nature. An extensive literature search on Islamic Principles and their relevance to architecture were undertaken with a view to identifying those that relate to residential architecture and how they were applied previously. Detailed designs of residential houses (which consisted of the site plans, floor plans, and elevations) designed for an already occupied by their Muslim clients were collected from different registered architects for analysis across Nigeria. In all, sixteen (16) architectural designs of such houses were chosen for analysis among which includes duplexes and Bungalows. The floor plan analysis of all samples was undertaken to establish the extent of use of architectural spaces, places, and elements on the site and floor plans to achieve privacy of occupants by the designers. The analysis of the floor plans was aimed at revealing the various levels of compliance with the designs with respect to the IDP to achieve privacy in the design of the samples as originally designed by the architects. In line with the 
objective of this paper, a design of a duplex among the sixteen samples was later selected among the sixteen samples to demonstrate how IDP could be integrated to achieve optimum family privacy. The choice of this sample was based upon the very low response of many of the identified IDP in the design of the selected duplex. The outcome of the redesign to achieve the privacy requirements indicated various elements of design which were either integrated, redesigned, reoriented or relocated in line with IDP and to achieve required family privacy that responds to IDP.

\section{THEORETICAL BACKGROUND FAMILY PRIVACY AND ITS RELEVANCE TO RESIDENTIAL DESIGN}

The issue of achieving privacy in a residential house and especially at family level has generated interest among scholars from across disciplines. This is partly due to its importance as a key requirement of housing across cultures [26]. In fact, some early works on a general aspect of privacy in residential houses, have identified family needs, spatial use pattern and (socially) self-regulated privacy processes as a basis for different house forms around the world [26], [27]. In specific, however, other scholars went further to explore a nexus between behavior (such as privacy) and its environmental context in Muslim houses [28]. In general, scholars concerned with the subject of privacy defined it as [29] a boundary between a person and his physical environment as well as a place that is considered as restricted to a stranger. Similarly, it is considered as a boundary for gender segregation and separation between the private life and public intercourse. The works Mary \& Khlood [30] is a good example of the former which described characteristics of Muslim women in the United States and the potential barriers to cervical cancer screening and prevention they may encounter due to the issue of privacy. Overall, scholars are agreeable that although, privacy needs are universal across cultures [31], [32] its interpretation and physical translation in-house design are, however, varied, in other words, it is culturally specific.

The two issues of privacy and achieving family privacy in a Muslim house have provided a study focus among many scholars [33], [34] \& [35]. Many of them claim in their studies that provision of family privacy (as an element of design) is a key factor which influenced the house forms and design in Muslim houses [21, [2]. Many of the current works classified privacy especially as seen from the view of the Muslim faithful to be of two kinds; visual and acoustic. There are others who opine that the olfactory privacy is important as well [3]. The visual type as the name suggest relates to protecting the family from unlawful "looking" by unrelated men, while the acoustic type refers unlawful 'listening'. The Olfactory, however, relates to the way smell or sensations especially from the kitchen which reaches visitors. The overall relevance of achieving privacy in the Muslim house is, therefore, to help in the preservation of interfamily life from strangers and to conceal information about the family (in the three aspects of "looking" listening and "smelling"). Although there are extant works on the issue on privacy in traditional houses, the contemporary houses have, however, been criticized for having little or no elements of design which concerns the rights of neighbors [36], [37]. Because of the seeming gap in design options to have Islamic elements of design [38] this paper aims to fill in this gap by way of demonstrating various design options in the design process to achieve the privacy needs of Muslim client's with recourse to IDP. This was done at three levels; privacy for the residents against the outside world, against those allowed into the house and among family members themselves. As shown in Figure 1 below, the privacy against the outside world refers to achieving privacy against the passersby and proximate neighbors to the house. Privacy against those allowable in the house includes achieving privacy of family against unrelated male visitors and servants such as male domestic workers and who may not live in the house. Lastly, privacy against family members themselves relates only to the members of the household who stay together within the house which include among others parents, grown-up daughters, male children below the age of puberty and related female visitors such as mother and father-in-laws.

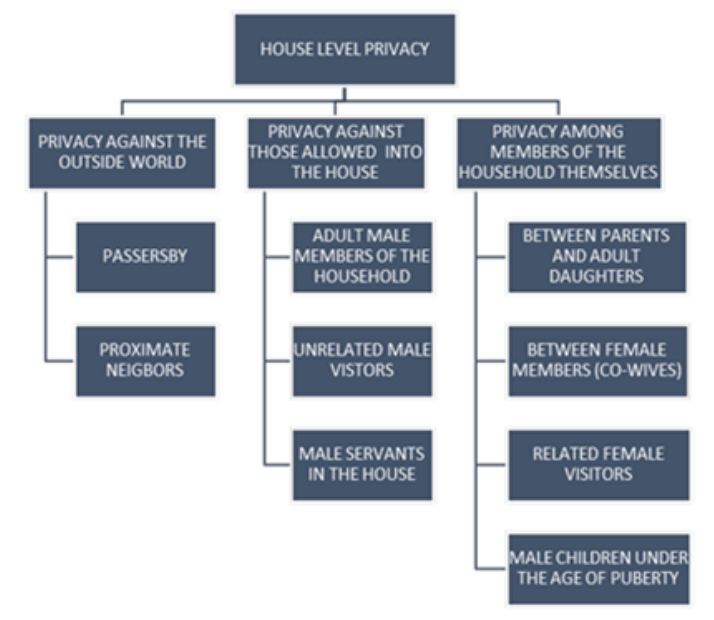

Figure 1. Showing Hierarchy for achieving family privacy in the Muslim home. (Source: Authors, 2017)

\section{SAMPLE FLOOR PLAN USED FOR THE STUDY (REDESIGN)}

The selected sample house used as a case study is a house designed for Nigerian Muslim family which supposedly addressed the privacy needs of the occupants. The designers were engaged by the client to not only address their spatial but also their spiritual requirements in terms of private provision. The house having been built has been occupied by the family for six years. As shown below in Figure 2 a (ground floor plan) \& b (first-floor plan), the house is a four bedroom duplex. The ground floor consists of functional spaces such as the main living room, service areas (kitchen, dining, laundry, and food storage), staircase and a guest room. Similarly, the first-floor plan consists of three bedrooms, private living and study room for the master. The floor plans presented below are as 
originally designed by the architect and were deemed to have addressed the clients brief.
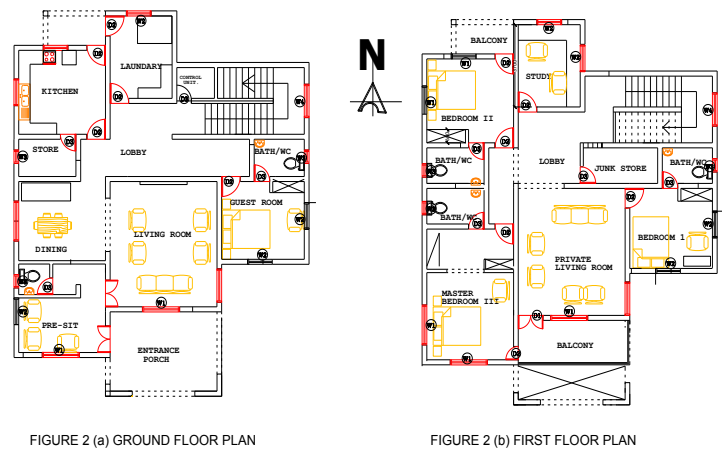

Figure 2 (a \& b). Showing ground and first floors of four bedroom duplex house used for the study (Design: Courtesy Arc: Arouno, 2016)

\section{DISCUSSION AND DATA PRESENTATION \\ FAMILY PRIVACY AGAINST THE OUTSIDE WORLD}

The "outside world' as used in this context refers to the passersby and proximate neighbors to the house. While the passersby refer to people who may have visual or acoustical contact with occupants (or both) while passing either on foot or in a vehicle, the proximate neighbors here include persons living in the next houses on both sides and rear. The following verses of the Quran and hadiths have been cited as basis among many to indicate the significance of achieving family privacy of a family against the aforementioned people. These include (Visual) - Quran, (24:27, 30 \& 33:53-55) and hadith include those narrated by Sahl bn Sad and Anas bn Malik in Sahih Bukhari no's 258 \& 260 (Volume 8, Book 74, Asking Permission) respectively.

\section{ARCHITECTURAL REDESIGN TO ACHIEVE PRIVACY AGAINST THE PASSERBY AND PROXIMATE NEIGHBORS}

The privacy at this level involves the use of the elements of the site to control the visual and acoustic exposure of occupants from neighboring houses. Achieving this type of privacy in the redesign task involve the integration of a number of design elements on the site plan. The first step is to integrate a perimeter fence made of block work or sand Crete on two adjoining sides and the side facing the major thoroughfare to a height above the eye level $(1.75 \mathrm{~m})$ as shown in Figure 3 (a). However, in situations where perimeter fence cannot be provided due to planning requirements, windows on the ground floor should be raised to the same height from the ground level so that the views of passersby from the street is prevented. Once the house is fully fenced, an introvert concept could be said to have been achieved as shown in Figure 3 (a). An introvert concept of design facilitates the transfer of family activities to the courtyard. In the redesigned site plan, three courtyards were created indicated as AAA, BBB, and CCC. The second step is to integrate as part of the perimeter fence design, vehicular and pedestrian gates to prevent views of the perimeter area from the passerby. Thirdly, the pedestrian gate entrance should likewise be designed such that direct views of the courtyards from passerby are prevented as shown in Figure 3(b). In the redesigned site plan below, the pedestrian gate here has been integrated with the gatehouse and opens to a blank wall of the gatehouse, thus, requires bending to the left to gain entrance to the house.

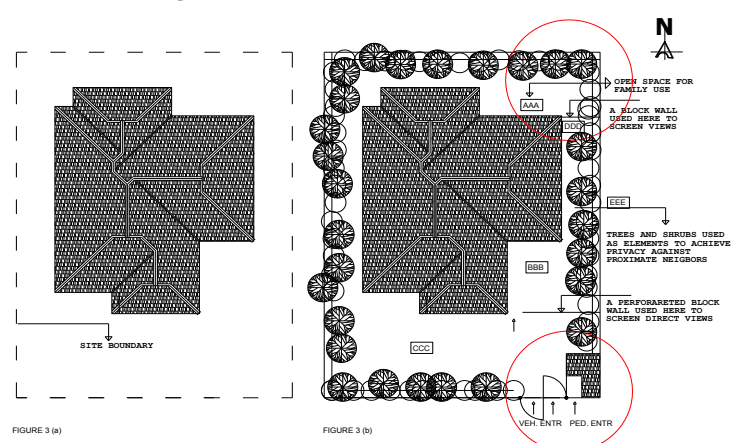

Figure $3(a \& b)$. The use of elements of the site plan to achieve privacy. Figure (a) is the existing situation, while Figure $3(b)$ is the redesigned site plan where privacy elements were integrated (Redesign: Authors, 2017)

Moreover, achieving privacy against the proximate neighbors involve the integration of other elements of design and modifications of others (see the existing situation in Figure 4 a). In the redesign task, therefore, the first task is to screen window openings on the first floor which opens to the proximate neighbor's courtyards using tall trees (such as slika spruces) and special shrubs as shown in Figure 4 (b). The use of the shrubs and tall trees (indicated as EEE on site plan) also protect the visual privacy of the proximate neighbors who live in single floor houses such as flats and bungalows and whose courtyards could be visually exposed. Secondly, the windows on the first floor can be raised in the redesign to a height above the eye level from floor level within the enclosure of the house and from $1.75 \mathrm{~m}$ from the suspended floor level or $4.90 \mathrm{~m}$ from the ground level (Figure 4c). Alternatively, windows which opened to courtyards of proximate neighbors and or faces main roads or thoroughfares could similarly be screened to prevent views by using perforated blocks which will prevent views to and from the neighbors yet allow natural light as well as air through the perforation (Figure 4d).

\section{FAMILY PRIVACY AGAINST PERSONS ALLOWED INTO THE HOUSE}

The second level of privacy is concerned with achieving family privacy on the ground floor as observed during data collection. This is achievable by integrating nonexistent design elements modification, redesign and or relocation of existing ones on the initial floor plan. The design task here is for the designer to restrict access to the first-floor level. Hence on ground floor level, visual and acoustic privacy requirements of family members targeted could be achieved against related adult male members, unrelated male and female visitors and servants who may be allowed in ground floor such as the domestic 


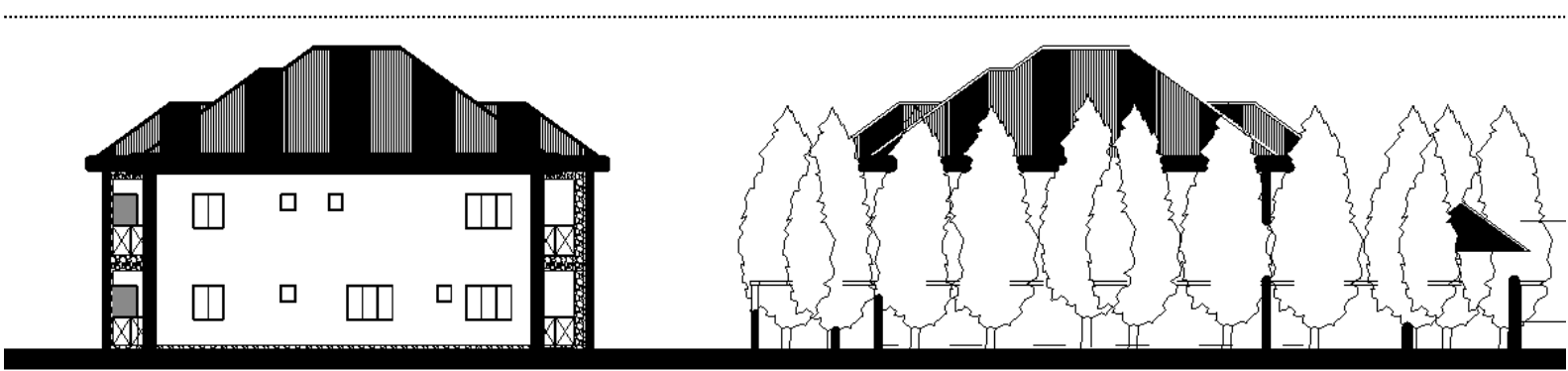

FIGURE 4 (a) SHOWING EXISTING SITUATION
WITHOOT ANY PRIVACY ELFMENT OF THE
SITE

FIGURE $4(\mathrm{~b})$ SHOWING HOW PERTMETER
FENCEE AND LONG TREES AND SHRUBS USED
TO ACHIVE PRTVACY AGATNST PROXTMATE
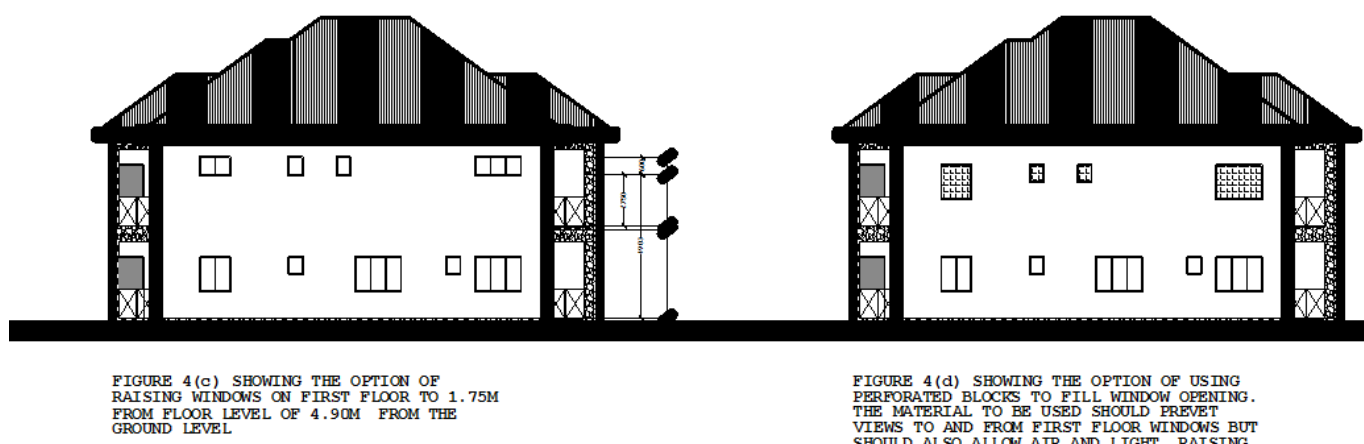

Figure 4 (a, b, c \& d) Using western side elevation of the floor plan to show options for achieving privacy on the first floor against proximate neighbors and passersby. For example, the use of shrubs and trees (a), raised window level to $1.75 \mathrm{~m}$ from suspended floor level or 4.90m from ground floor level (b) and ingenious use of perforated blocks or Aluminum foil to screen windows (e) (Redesign: Authors, 2017)

staff. And because, the privacy against those allowed into the house relates to visual, acoustic and olfactory (observations from data collected) scholars relate the following IDP as a basis from the Al Qur'an and Hadith among many to indicate the significance of achieving privacy of family members against those allowed into the house. These include IDP on (acoustic) Quran (49:4 -5 \& 33:32-33) and Hadiths narrated by Abdullah in Sahih Bukhari no 305 (Volume 8, Book 74 Asking Permission) and another Hadith which scholars cite to justify the olfactory aspect was as reported by Abu Darr in Sahih Bukhari no. 6357, Book 32) in which the contents of the Hadith suggests adding more water content of food so that neighbor can get share having felt the smell and aroma of the cooked food from the neighbors (see commentary in Sahih Muslim).

ARCHITECTURAL CONSIDERATIONS AND REDESIGN TO ACHIEVE FAMILY PRIVACY AGAINST PERSONS ALLOWED INTO THE HOUSE

The first design task concerns the entrance porch and pre-set/pre-entrance which were provided in the initial design of the ground floor level as shown in Figure 5(a). These elements were retained because they serve as spaces to address servants and to receive unrelated visitors who may not necessarily be admitted into the house. In the initial design of the ground floor plan, a guest room was provided (Figure 5b. 1) as accommodation for overnight guests. To achieve the required privacy, however, the guest room entrance door which was initially located and accessed from the lobby was relocated so that access to the guest room from outside of the house to avoid visual contact with female members of the family at the lobby (Figure 5b. 2). Secondly, achieving privacy against unrelated female visitors requires dedicated female living room on this floor to receive and entertain them, hence the lobby provided in the initial floor plan was redesigned to serve as the female living room (Figure 5b. 3). Thirdly, further visual privacy is enhanced between visitors in the main living room and the redesigned (lobby which now serves as a female living room) if a separate female entrance door is provided (backdoor). To achieve this the space provided as service control space in the initial design was opened up (redesigned) where an entrance door was now integrated (Figure 5b.4). While this door will help restrict movement of female visitors through the main living room (where male residents use often) also to restrict passing through the kitchen which also requires some level of privacy during the course of food preparation.

Moreover, acoustic privacy can be enhanced if a soundproof door is integrated into the opening which links the dining area to the kitchen (Figure $5 \mathrm{~b}$. 5), as this will help reduce the transmission of sound from the kitchen. The integrated door will also prevent direct views to the lobby (which has been converted to female living room). Similarly, to further prevent views from the dining area to the kitchen, there is the need to relocate the kitchen door which directly faces the dining area (Figure 5b. 6) so that the kitchen door will now face the lobby which has now been converted to a female living room. Additionally, integrating a communication door (Figure 5b. 7) between the male and female living rooms will further enhance privacy 
for the family specifically related male members who may be allowed into the house, which prevent going through the dining area. Also, the integration of verandah or shade at the rear part of the house (Figure 5b. 8) at the kitchen area provide visual privacy for female domestic staff and other female members of the household who work around the kitchen area from neighbors on the first-floor level.

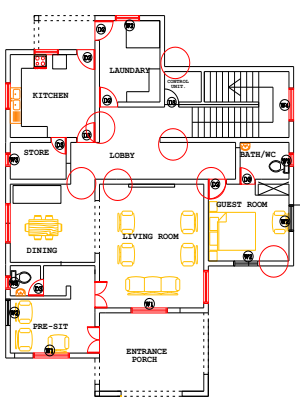

FIGURE 5 (a) GROUND FLOOR PLAN

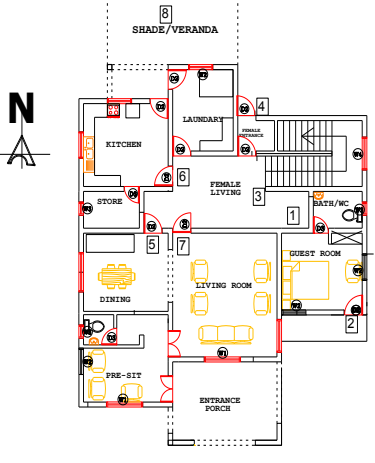

FIGURE 5 (b) GROUND FLOOR PLAN
Figure $5(\mathrm{a} \& \mathrm{~b})$. Showing initial and modified ground floor plans to achieve family privacy at the second level (those allowed into the house). The circles as shown in the initial floor plan (a) indicate elements integrated to provide privacy (1-8) (Redesign: Authors, 2017)

\section{PRIVACY AMONG FAMILY MEMBERS}

Privacy among family members within the house relates to how spaces and design elements facilitate the way family interacts with each other individually (parents, childreno and collectively as well as how the female family members receive and entertain related female visitors such as mothers, aunties, sisters, mother-in-laws and sister's in-laws. The family members were generally noted to live on the first floor and include the parents, grown-up daughters and male children below the age of puberty. Some verses in the Al Qur'an Quran (24:28 \& 4:23) were cited as a basis to indicate the significance of achieving privacy among family members themselves and further supported by a hadith (305 Sahih Bukhari: Volume 8 , Book 74 Asking Permission) narrated by Abdullah.

\section{ARCHITECTURAL REDESIGN TO ACHIEVE PRIVACY AMONG FAMILY MEMBERS THEMSELVES}

Separation of spaces for interactions between parents grown up daughters and related female visitors provides privacy to occupants at a time. Key to achieving this type of privacy is the need to provide separate living rooms for the children and parents which has been achieved by redesign of lobby to semiprivate living room and the main living modified as most private living room respectively as shown in the existing floor plan Figure 6(a) and modified floor plans in Figure 6(b. 9). The semi-private living (is expected to serve grown-up daughters as well as the area for receiving and entertaining related female visitors such as aunts, sisters, female friends, neighbors and acquaintances, while the most private living room should be used to serve the master and his wife and to receive and entertain mothers, mother-in-laws and unties. Similarly, to achieve visual as well as acoustic privacy between bedrooms II and III, the bedroom doors should also not face each other as in the initially designed, hence, a wall as an element of the design was thus extended to screen the two opposite bedroom doors (Figure 6b.10). Using this wall to screen direct views from the two opposite bedroom doors prevents visual intrusion as well as reduce sound transmission. Lastly, it is possible to also enhance
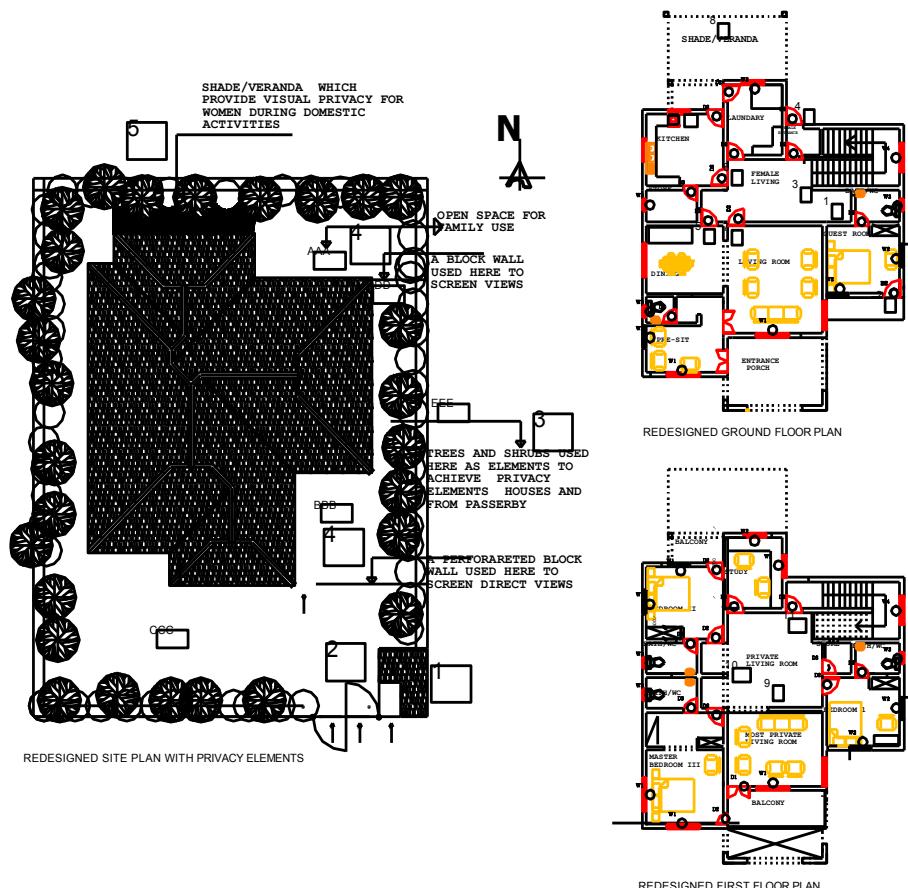
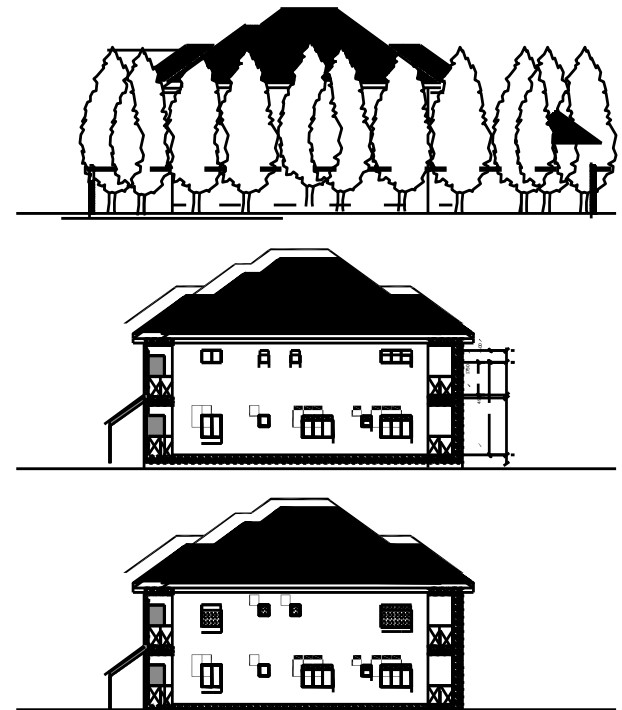

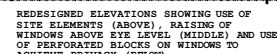

Figure 7. Showing redesigned site plan (left), Floor Plans (center) and Elevations. Redesign: Authors, 2017)

14 | Journal of Islamic Architecture, 5(1) June 2018 
visual privacy for the womenfolk in the house when adult sons come visiting. An architectural design option here is through the provision of access where a door was integrated at the head of the staircase (Figure 6 b. 11). A closed-door facilitates seeking for permission as enjoined in the al-Quran before entry is allowed.
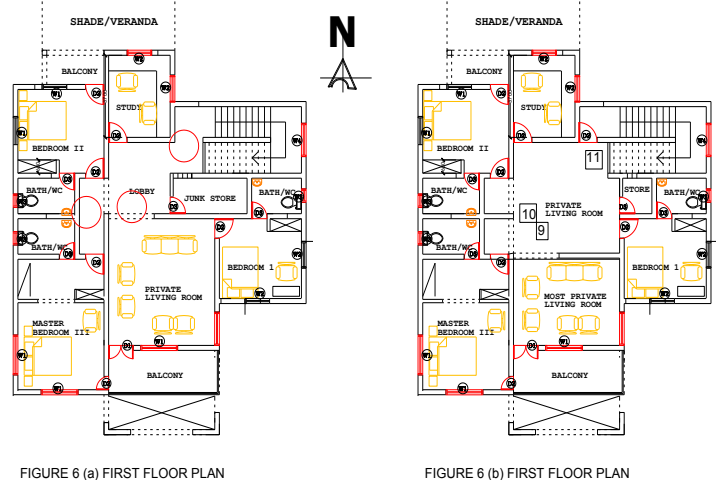

Figure $6(a \& b)$. Showing initial and modified ground floor plans to achieve family privacy at the third level (family member's level). The circles as shown in the initial floor plan (a) indicate elements integrated or modified to provide privacy (9-11) (Redesign: Authors, 2017)

\section{SUMMARY AND CONCLUSION} SUMMARY OF REDESIGNED DUPLEX HOUSE

Based upon the inspiration drawn from the Islamic design principles from the two sources of Shariah i.e. Quran and Hadiths, it has been shown that there are various design options to achieve family privacy in the design of a house for the Muslim client. As shown in the preceding pages, privacy was achieved against the outside world, those allowed into the house and lastly among the inner circle of the family themselves. At the first level, (against the outside world), occupants of the house were protected from direct and indirect views of passersby and proximate neighbors. At the second level (those allowed into the house), a direct physical contact was controlled in the redesigned ground floor plan between the female members of the household from unrelated male visitors, acquaintances, business associates and male servants. The last level of privacy in the redesigned first-floor plan was among the inner circle of family members (among co-wives, parents, and daughters) as well as related female visitors such as mothers, aunties and sisters. Overall, a total of seventeen architectural elements and spaces were either integrated into the

Table 1. A Taxonomy of privacy elements provided in the initial and the final redesign duplex house showing details of elements integrated, relocated or redesigned.

It also shows the type of privacy provided, beneficiaries of provided privacy, the privacy predators and the basis of IDP from Sharia.

(Source; Authors, 2017)

\begin{tabular}{|c|c|c|c|c|c|c|c|c|c|c|c|}
\hline \multirow[t]{2}{*}{$\begin{array}{l}\text { Design } \\
\text { stage }\end{array}$} & \multirow{2}{*}{$\begin{array}{l}\text { Architec- } \\
\text { tural } \\
\text { elements } \\
\text { of privacy } \\
\text { provided } \\
\text { in the } \\
\text { initial } \\
\text { design }\end{array}$} & \multirow{2}{*}{$\begin{array}{l}\text { Architectur- } \\
\text { al elements } \\
\text { of privacy } \\
\text { provided in } \\
\text { the final } \\
\text { design }\end{array}$} & \multicolumn{3}{|c|}{$\begin{array}{l}\text { Architectural elements of } \\
\text { privacy added in the redesign } \\
\text { of house }\end{array}$} & \multicolumn{3}{|c|}{$\begin{array}{l}\text { Type of privacy } \\
\text { achieved }\end{array}$} & \multirow[t]{2}{*}{$\begin{array}{l}\text { Privacy } \\
\text { predators }\end{array}$} & \multirow[t]{2}{*}{$\begin{array}{l}\text { Privacy } \\
\text { benefi- } \\
\text { ciaries }\end{array}$} & \multirow{2}{*}{$\begin{array}{l}\text { Islamic Design } \\
\text { Principles used as } \\
\text { the basis from the } \\
\text { Sharia sources (Al- } \\
\text { Quran and Hadith) }\end{array}$} \\
\hline & & & $\begin{array}{l}\text { Inte- } \\
\text { grated } \\
\text { (elemen } \\
\text { ts) }\end{array}$ & $\begin{array}{l}\text { Rede- } \\
\text { sign } \\
\text { (elem } \\
\text { ents) }\end{array}$ & $\begin{array}{l}\text { Relo- } \\
\text { cated } \\
\text { (elem } \\
\text { ents) }\end{array}$ & $\begin{array}{l}\text { Visual } \\
\text { (priva } \\
\text { cy) }\end{array}$ & $\begin{array}{l}\text { Acou } \\
\text { stic } \\
\text { (priv } \\
\text { acy) }\end{array}$ & $\begin{array}{l}\text { Olfac- } \\
\text { tory } \\
\text { (priva } \\
\text { cy) }\end{array}$ & & & \\
\hline \multirow{8}{*}{$\begin{array}{l}\text { Site } \\
\text { Plan: } \\
\text { Privacy } \\
\text { against } \\
\text { the } \\
\text { outside } \\
\text { world }\end{array}$} & \multirow{8}{*}{$\begin{array}{l}\text { Normal } \\
\text { height } \\
\text { windows } \\
\text { on eleva- } \\
\text { tion }\end{array}$} & $\begin{array}{l}\text { Perimeter } \\
\text { fence (1) }\end{array}$ & $x$ & & & $x$ & & & $\begin{array}{l}\text { Passerby } \\
\text { \& Prox. } \\
\text { Nbor }\end{array}$ & $\begin{array}{l}\text { All } \\
\text { resi- } \\
\text { dents }\end{array}$ & \multirow{8}{*}{$\begin{array}{l}\text { Visual - Quran, } \\
\text { (Chapter 24:27, 30) } \\
\text { (Chapter } 33: 53 \text { \& } \\
55) \\
\text { Hadith: (Visual) } \\
\text { Sahih Bukhari: } \\
\text { Volume 8, Book } 74 \\
\text { (Asking Permis- } \\
\text { sion), Number } 258 \\
\text { (Sahl bn Sad) } \\
\\
\text { Sahih Bukhari: } \\
\text { Volume 8, Book } 74 \\
\text { (Asking Permis- } \\
\text { sion), Number } 260 \\
\text { (Anas bn Malik) }\end{array}$} \\
\hline & & $\begin{array}{l}\text { Entrance \& } \\
\text { P. gate (2) }\end{array}$ & $x$ & & & $x$ & & & Passerby & $\begin{array}{l}\text { All } \\
\text { resi- } \\
\text { dents }\end{array}$ & \\
\hline & & $\begin{array}{l}\text { Trees and } \\
\text { shrubs (3) }\end{array}$ & $x$ & & & $x$ & & & $\begin{array}{l}\text { Passerby } \\
\text { \& Prox. } \\
\text { Nbor }\end{array}$ & $\begin{array}{l}\text { F. F. } \\
\text { Occup. }\end{array}$ & \\
\hline & & $\begin{array}{l}\text { Wall/ court- } \\
\text { yard (4) }\end{array}$ & $x$ & & & $x$ & & & $\begin{array}{l}\text { Passerby } \\
\text { \& Prox. } \\
\text { Nbor }\end{array}$ & $\begin{array}{l}\text { All } \\
\text { resi- } \\
\text { dents }\end{array}$ & \\
\hline & & $\begin{array}{l}\text { Shade/ } \\
\text { verandah } \\
\text { (5) }\end{array}$ & $x$ & & & $x$ & & & $\begin{array}{l}\text { Proximate } \\
\text { Neighbor }\end{array}$ & $\begin{array}{l}\text { Feml. } \\
\text { Resi- } \\
\text { dent. }\end{array}$ & \\
\hline & & Elevations & & & & & & & & & \\
\hline & & $\begin{array}{l}\text { Raised } \\
\text { window } \\
\text { level }\end{array}$ & & $x$ & & $x$ & & & $\begin{array}{l}\text { Passerby } \\
\text { \& Prox. } \\
\text { Nbor }\end{array}$ & & \\
\hline & & $\begin{array}{l}\text { Screened } \\
\text { windows }\end{array}$ & & $x$ & & $x$ & & & $\begin{array}{l}\text { Passerby } \\
\text { \& Prox. } \\
\text { Nbor }\end{array}$ & & \\
\hline
\end{tabular}


Integrating Islamic Design Principles For Achieving Family Privacy In Residential Architecture

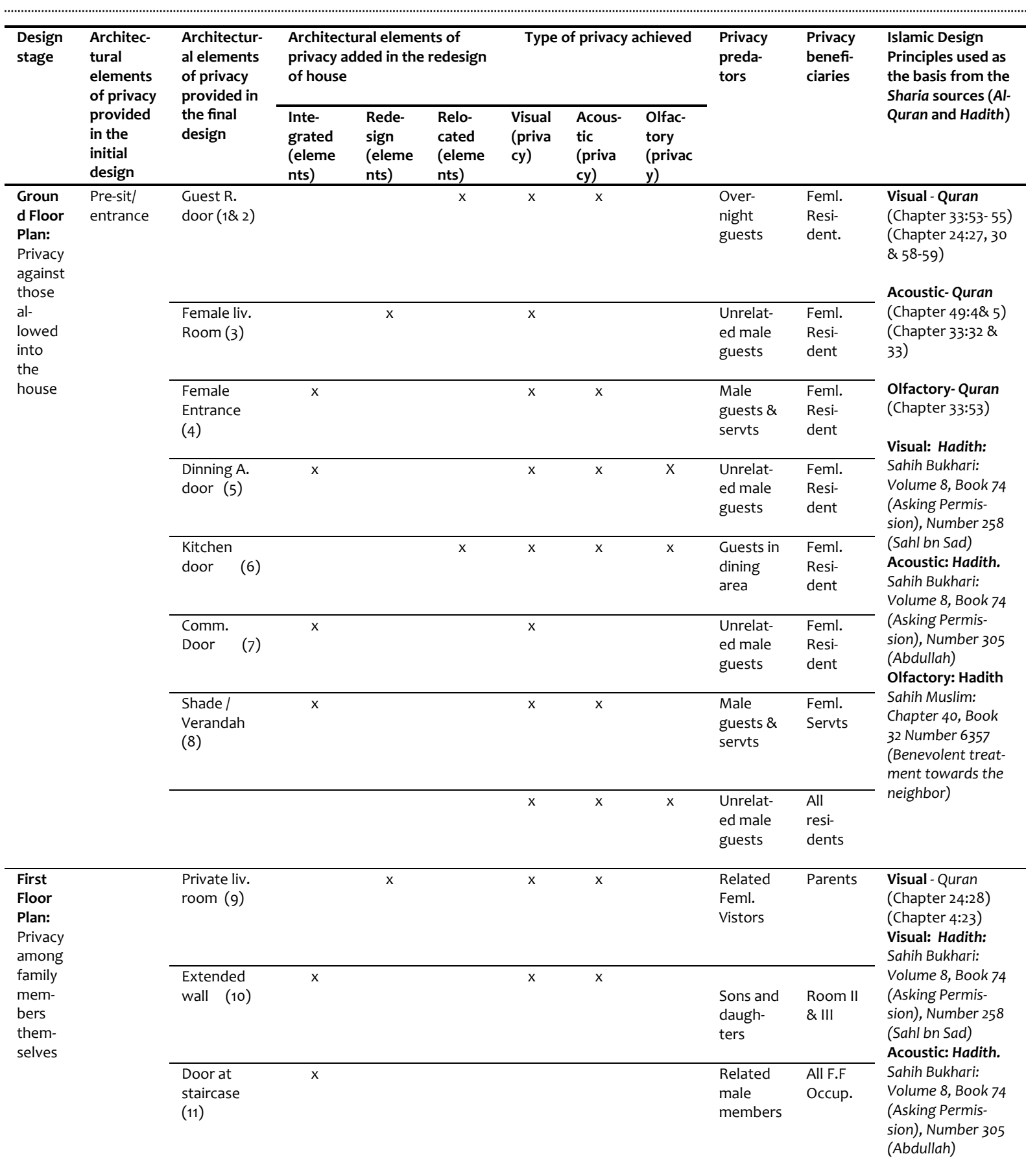

original design, redesigned or relocated to achieve family privacy in the redesign task. Out of this number, only one (pre-entrance) was retained as it was found to satisfy the privacy requirements. As shown below in Figure 7, five design elements were integrated into the redesigned site plan to achieve the required privacy (15) for the first privacy level. Similarly, for the second privacy level, a total of eight privacy design elements were used on the ground floor plan, four were integrated $(4,5,7$, and 8$)$, two were redesigned ( 3 and 1) and two others were relocated ( 2 and 6$)$. For privacy among family members, however, two elements were integrated (10 and 11), one other was redesigned (9), and on the elevations, the window was the major design element and was redesigned only.

In general, the various design elements that were either integrated, redesigned or modified on existing site plans as shown in Table 1 below were aimed at achieving various aspects of family privacy requirements. For example, five design elements (1-5) were integrated achieve family privacy against the outside world specifically against proximate neighbors and the passersby and occupants who live on the first floor of the house. The outdoor open spaces (AAA, $B B B, C C C$ \& DDD) provide privacy for the female members of the household during the day against unrelated male visitors and servants. Similarly, at the ground floor, the design elements (1-8) were to 
provide visual and acoustic privacy to the womenfolk from overnight guests, male visitors, and domestic staff. On the second floor, the design elements (9-11) were integrated to provide privacy to the female members of the household against related male members of the household, views of passersby and proximate neighbors as well as prevent views from the reference house on to the courtyards of proximate neighbor's house.

\section{CONCLUSION}

It has been shown that there are various design options as well as elements that are open and available to architects and other designers in the built environment to achieve various aspects of privacy at the level of a residential house. Hence, the various design elements used to achieve privacy in the redesign task could be said to address specific issues for the family. For example, the privacy design elements of site plan help residents to exercise the power over information which relates to the family alone by freeing up the perimeter area for domestic activities and interactions among female members of the household and their domestic workers without being exposed to the outside world. These elements also help the family to maintain its anonymity and individuality which ultimately increases confidence among family members as well as reduce their security exposure. The elements of design on the ground floor which provide enabling environment for the entertainment, discussions, and meetings with unrelated male visitors help to create personal distance between unrelated male visitors and female residents which ultimately reduces sexual tension among them [6]. Achieving privacy among family members in the house promote high ethical behavior among children themselves and towards their parents, high moral growth among children and enhanced spiritual quality of life among all family members. Overall, it has been shown using the case study of an existing floor plan of a duplex house on the need for architects and designers to understand client's spiritual requirements and contextually provide their Muslim clients and other like minds with requisite privacy needs in designing their residential houses. When IDP is used in the design of the Muslim client architects and professionals would have succeeded in shaping their behavior of by way of the spaces that they create and elements they used. This study points that privacy is achievable for the Muslim clients and those who desire it, especially when considered at the initial design stage. This is especially possible through the integration elements of design based on knowledge drawn from Islamic design principles.

\section{REFERENCES}

Qur'an (Chapter 24:27, 30), (Chapter 33:53 \& 55),

(Chapter 24: 58-59), (Chapter 49:4\& 5)

(Chapter 33:32 \& 33), (Chapter 24:28)

(Chapter 4:23), (Chapter 4;29), (Chapter 44:10),

(Chapter 18;80), (Chapter 24;27)
Hadith. Sahih Bukhari: Volume 8, Book 74 (Asking Permission), Number 258 (Sahl bn Sad), Sahih Bukhari: Volume 8, Book 74 (Asking Permission), Number 260 (Anas bn Malik), Sahih Bukhari: Volume 8, Book 74 (Asking Permission), Number 305 (Abdullah), Sahih Muslim: Chapter 40, Book 32 Number 6357 (Benevolent treatment towards the neighbor)

[1] B. Hamza, Impact of Islamic Built Environment Criteria on the Architecture of the Urban Hausa Traditional House, Northern Nigeria. An unpublished Ph.D. thesis at International Islamic University, Malaysia, 2010.

[2] A. Abdul Rahim, "A concept of the clean toilet from the Islamic perspective," Journal of Islam Built Environ. vol 1 (1), 2005, pp.71-84.

[3] A. Abdul Rahim, "Public toilets from Islamic perspectives: Malaysian experience," World toilet expo, Bangkok, Thailand, organized by World Toilet Organization and Forum (WTEF), 2006.

[4] B. S. Hakim, Arabic-Islamic Cities: Building and Planning Principles. London: KPI Ltd, 1986.

[5] B. S. Hakim \& A. Zubair, "Rules for the built environment in 19th century Northern Nigeria," Journal of Architectural and Planning research. vol 23 (1), 2006, pp. 1-25.

[6] H. Mortada, Traditional Islamic Principles of Built Environment. Routledge Curzon, New York (NY): Taylor Francis Group, 2004.

[7] M. N. Shuhaida, "Spirit of the Shariah," I. Zen, S. J. Kasim \& N. M. Nawawi (Eds), an Anthology of Essays on Integrating Islamic Values in the Theory and Practice of Architecture and Built Environment, Kuala Lumpur, Malaysia: MPH Group printing, 2009.

[8] A. Abdul Rahim, Housing from Islamic Perspective, Malaysia: IIUM Press, 2008.

[9] S. Omer, Studies in the Islamic Built Environment. Malaysia: IIUM Press, 2004.

[10] W. B. Hallaq, Law and Legal Theory in Classical Medieval Islam, Brookfield: Variorum, 1995.

[11] A. Sarkawi, "Deriving Islamic Law of the Built Environment from Its Sources: a Conceptual Framework". I. Zen, S. J. Kasim \& N. M. Nawawi (Eds), an Anthology of Essays on Integrating Islamic Values in the Theory and Practice of Architecture and Built Environment. Kuala Lumpur, Malaysia: MPH Group printing, 2009. 
[12] H. Gulzer, "Faith is the Architect, Reflections on the Mosque," S. Ozkan (Eds). Faith and the Built Environment, Suisse: Comportments publishers, 1996.

[13] A. M. Kani, K. A. Gandi (Eds), State and societies in Sokoto Caliphate, Aria: Gaskiya Corporation, 1990.

[14] J. O. Hunwick, "Arabic Literature of Africa," Volume 2, The writings of central Sudanic Africa. Leiden: E.J Brill, 1995.

[15] F. W. Schwertdfeger, "Housing in Zaria". In Oliver, P (ed), Shelter in Africa, London: Barrie and Jenkins Ltd., 1976, pp. 57-78.

[16] B. I. Hamza B, \& M. Abdulkarim, "Islamic Aspects of the Urban Hausa, Traditional House in Northern Nigeria," ARCHISEACH; Journal of the Department of Architecture, Vol. 1 no. 2, September, 2009, pp. 16-26.

[17] N. A. Akeel, "Urban design and the Islamic city in the light of Islamic values," I. Zen, S. J. Kasim \& N. M. Nawawi (Eds), an Anthology of Essays on Integrating Islamic Values in the Theory and Practice of Architecture and Built Environment. Kuala Lumpur: MPH Group printing, 2009.

[18] K. Kivanc, On the Aesthetics of Space in Ottoman House: Tracing the Eternal in Ephemeral, www.let.leidenuniv.nl/tcim/tulp/ Research/kk1.pdf. Retrieved in 2008.

[19] K. Van Nieuwkerk, "Creating an Islamic cultural sphere: contested notions of art, leisure, and entertainment," Contemporary Islam, vol 2(3), 2008, pp.169-176.

[20] J. Sixsmith, "The meaning of home: An exploratory study of environmental experience," Journal of Environmental Psychology, vol 6 (4), 1986, pp. 281-298.

[21] A. Zaiton \& H. Ahmad, The Influence of Design Attributes of Terrace Housing on the privacy of Malay Families, Conference paper presented at the World Housing Congress, Terengganu, Malaysia, 2007.

[22] R. Azizah, R.H. Putri, "Implementation of hijab concept in Arab house Pasar Kliwon Surakarta," Journal of Islamic Architecture, vol 2 (3), 2013, pp. 106-113.

[23] A. Bahammam, "Factors which influence the size of contemporary dwelling, Riyadh Saudi Arabia," Habitat International, vol 22 (4), 1998, pp. 557-570.
[24] A. Zawya, First Islamic compliant resort to open in the Maldives. Retrieved October 15, 2011, from http://www.zawya.com/story.cfm/ sidZAWYA 20110503085858, 2011.

[25] M. A. Al-Hussayen, "Spatial characteristics of traditional houses of Al-Medinah, Saudi Arabia," Architectural Science Review. vol 42 (4), 1999, pp. 271-282.

[26] A. Rapoport, House form and Culture, Englewood Cliffs, N.J.: Prentice-Hall INC., 1969.

[27] A. Tawfik, "Privacy as the basis of Architectural planning in Saudi Arabia," in S. Ozkan (eds), Faith and the Built Environment, Comportments, 1996.

[28] S. Wapner, J. Demick, T. Yamamoto, \& H. Minami, (Eds). Theoretical Perspectives in Environment-Behavior Research: Underlying Assumptions, Research Problems, and Methodology, New York: Kluwer Academic/ Plenum Publishers, 2000.

[29] T. Fahey, "Family Privacy; Conceptual and empirical reflections," Journal of the British Sociological Association, vol 29(4), 1995, pp.687-694.

[30] E. G. Mary \& S. Khlood, "Modesty Matters: Cultural Sensitivity and Cervical Cancer Prevention in Muslim Women in the United States," Nursing for Women's Health. vol 17(3). 2013, pp.210-217.

[31] I, Altman, "Privacy Regulation; culturally universal or culturally specific," Journal of Social, vol (3)3, 1977, pp.66-84.

[32] P. B. Newell, "Perspectives on Privacy," Journal of Environmental Psychology, vol 15(2), 1995, pp. $311-320$

[33] A. Danshpour, "The concept of privacy in housing based on Islamic teachings," Proceedings of first Iranian student's scientific conference, Malaysia, 2011.

[34] M. A. Al-Hussayen, "Spatial characteristics of traditional houses of Al-Medinah, Saudi Arabia," Architectural Science Review. vol. 42 (4), 1999, pp.271-282.

[35] K. Al-Kodmany, "Residential visual privacy; traditional and modern Architecture and urban design," Journal of Urban Design. vol 4 (3). 1999, pp.283-311

[36] M. H. Al-Ibrabim, "The Criticism of Modern Architecture in Saudi Arabia," E-Journal of 
Architecture and Planning, 2003, pp. 63-80, http://digital.library.ksu.edu.sa/V2M35R116.pd

[37] M. E. Omar, Translation of Islamic Culture into Arabian Architecture, Master thesis. Curtin University, Australia. http://adt.curtin.edu.au/ theses/available/adtWCU20020506.125441/
unrestricted/08Chapter6.pdf. 2000

[38] O. Zulkeplee, A. Rosemary, \& B.Laurie. "Privacy, Moderation, Hospitality and the design of Muslim homes: a literature review," Frontiers of Architectural Research. vol 4, (1), 2015, pp.1223. 